\title{
A Geochemical Approach and Industrial Utilization of Some Marble Bodies from Ubo River Area and Environs, Southwestern Nigeria
}

\section{*1ODOKUMA-ALONGE, O; ${ }^{2}$ CHIBUZOR, NS; ${ }^{1 O G B A M I K H U M I, ~ A ~}$}

\author{
${ }^{*}$ Department of Geology, Faculty of Physical Sciences, University of Benin, Benin City, Edo State, Nigeria \\ ${ }^{2}$ Department of Geological Sciences, Faculty of Physical Sciences, Nnamdi Azikiwe University, Awka, Anambra State, Nigeria \\ *lCorresponding Author Email: ovie.odokuma-alonge@uniben.edu
}

\begin{abstract}
Marble bodies occur in Ubo River Area as lenses of rocks. Seven (07) marble samples were obtained, analyzed and subjected to X-Ray Flourescence (XRF) analysis to determine both the major and trace elemental composition of the samples. The analysis revealed high $\mathrm{CaO}$ values (52.23-58.10 wt. \%) and moderate values for $\mathrm{SiO}_{2}$ (7.50-10.43wt. \%), fairly low values for $\mathrm{Al}_{2} \mathrm{O}_{3}\left(2.30-4.21\right.$ wt. \%), $\mathrm{Fe}_{2} \mathrm{O}_{3}(2.62-5.15$ wt. \%), $\mathrm{MgO}$ $\left(0.42-0.7\right.$ wt. \%), $\mathrm{MnO}\left(0.01-0.06\right.$ wt. \%), $\mathrm{K}_{2} \mathrm{O}\left(0.32-1.55\right.$ wt. \%) and $\mathrm{Na}_{2} \mathrm{O}(0.01-0.03$ wt. \%), respectively. Variation plots involving $\mathrm{Na}_{2} \mathrm{O} / \mathrm{Al}_{2} \mathrm{O}_{3}$ vs $\mathrm{K}_{2} \mathrm{O} / \mathrm{Al}_{2} \mathrm{O}_{3}$ reveal sedimentary progenitors for the rocks. The fairly high $\mathrm{SiO}_{2}$ and low $\mathrm{K}_{2} \mathrm{O}$ content is an indication of the environment of deposition and may have been in a shallow marine environment with fair input of classic sediments into the system. The relatively high $\mathrm{CaO}$ content, moderate $\mathrm{SiO}_{2}$ content and fairly low $\mathrm{Al}_{2} \mathrm{O}_{3}$ and $\mathrm{Fe}_{2} \mathrm{O}_{3}$ values indicates a fair degree of purity of the parent rock, hence its suitability as a raw material in the industrial sector.
\end{abstract}

DOI: https://dx.doi.org/10.4314/jasem.v24i4.17

Copyright: Copyright $(\mathrm{C} 2020$ Odokuma-Alonge et al. This is an open access article distributed under the Creative Commons Attribution License (CCL), which permits unrestricted use, distribution, and reproduction in any medium, provided the original work is properly cited.

Dates: Received: 11 February 2020; Revised: 14 March 2020; Accepted: 22 March 2020

Keywords: Clastic, Deposition, Environment, Progenitor, Marble, Chemical

Marble is a metamorphic rock formed when limestone is subjected to changes in heat and pressure. Marble forms under such conditions because the limestone undergoes a recrystallization process in the solid state (Gillen, 1982). Marble is a rock, composed primarily of calcite $\left(\mathrm{CaCO}_{3}\right)$ and usually contains other impurities such as muscovite, biotite, pyrite, graphite and chlorite etc. The variety of colours exhibited by marble are a consequence of minor amount of the aforementioned minerals incorporated into the system during metamorphism. Marble fizzes on contact with dilute hydrochloric acid ( $\mathrm{HCl}$ (Robert, 1979). Marble bodies generally form at convergent plate boundaries, where large areas of the earth's crust are exposed to regional metamorphism. Some marble bodies form by contact metamorphism when a hot magma body heats adjacent limestone or dolostone (Robert, 1979). Prior to metamorphism, the calcite in the limestone is often in the form of lithified fossils with other biological debris. During metamorphism, calcite recrystallizes and the texture of the rocks becomes massive. Marble subjected to low grade regional metamorphism, possesses fine crystals, but metamorphism progresses the crystals increase in size. Clay minerals within the marble transform to micaceous and more complex silicate mineral as metamorphism progresses (Touret, 1997). The aim of this study is to determine the chemical composition of the marble bodies with a view to bring to the fore the probable origin of the noncalcareous materials.

Geological Setting: The study area lies approximately between longitude E006 00 '26.7' to E006 26 '20.8' and latitude $\mathrm{N} 07^{\circ} 05^{\prime} 26.7^{\prime \prime}$ to $7^{\circ} 26^{\prime} 00^{\prime \prime}$ on a scale of 1:100,000 on Auchi Sheet 266. The study area forms part of the crystalline basement complex rocks (Figure 1). The Precambrian basement complex of Nigeria is polycyclic in nature (Ajibade and Fitches, 1988) as it has been affected by more than one orogenic event accompanied by deformation and metamorphism. The most prominent of these being the Pan African Orogeny which overprinted and obliterated to a large extent earlier structures of the basement rocks (Fitches et al., 1985). The Precambrian basement rocks include the migmatized gneissic complex of Archean to Early Proterozoic age (Dada, 1999; Dada et al., 1993; Grant et al., 1972), the N-S trending Schist belts of the Upper Proterozoic age (Rahaman, 1988) and the older granitoids of the Pan African age (Fitches et al., 1985). The polycyclic migmatized gneiss complex rocks are the most widespread and occupy about $60 \%$ of the total surface area of the basement rocks (Rahaman and Ocan, 1988). The Schist belts occur as synformal troughs infolded into the migmatite-gneiss complexes

${ }^{* 1}$ Corresponding Author Email: ovie.odokuma-alonge@uniben.edu 
and are largely sediment dominated. The most important lithologies are pelites, banded-iron formation, quartzites, marbles and calc-silicate rocks (Turner, 1983).

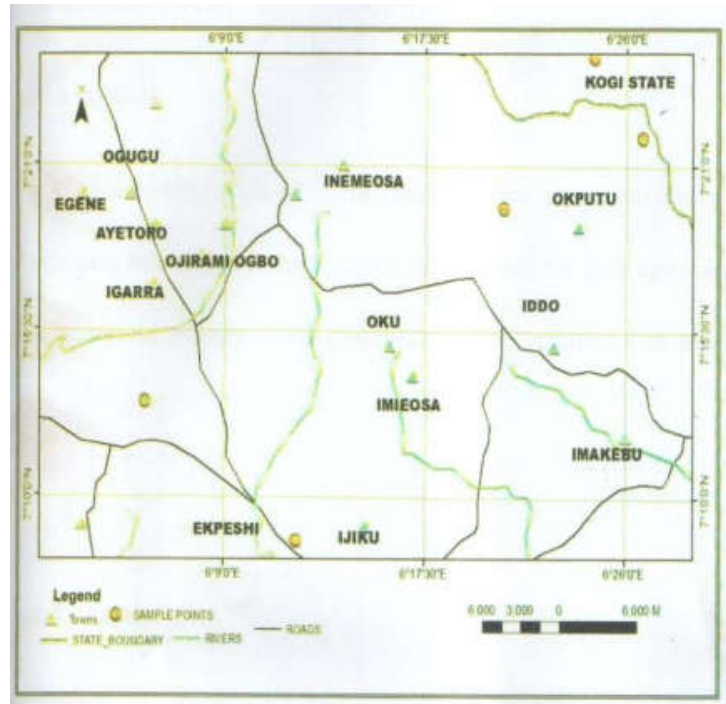

Fig 1: The location map of the study area (modified after GSN, 1974)



Fig 2: The geological map of the study area (modified after GSN, 1974)

The contact between the migmatite- gneiss complex rocks and the metasediments are fault bound in most cases (Odeyemi, 1988). The Older Granites represents a diverse magmatic cycle $(750 \pm 450 \mathrm{Ma})$ associated with the Pan African Orogeny (Woakes et al., 1987). Rocks belonging to this suite vary in composition from tonalites-granodiorites-granites. Syenitic and granodiorite rocks appear to be most common (Rahaman, 1988). The marble bodies studied for this paper are emplaced within the quartz mica schists near Ikpeshi area and the migmatites towards the north eastern axis of the area near Ubo River Area (Figure 2 ), respectively. A number of authors have worked on marble bodies within the basement complex such as Emofurieta and Aganbi, 2008; Obasi et al., 2015; Ogungbuyi et al., 2013; Onimisi et al., 2013; Bassey and Obasi, 2012 to mention a few.

\section{MATERIALS AND METHODS}

A number of geological tools were employed for this study and they include the Global Positioning System (GPS), compass clinometer, the sledge hammer, sampling bag, field note books, writing material and dilute hydrochloric acid ( $\mathrm{HCl})$. Seven (7) rock samples (fresh) were collected using the sledge hammer from different locations of the marble bodies in the study area. The GPS was used to determine the coordinates where the samples were collected. The rock samples were labeled and kept in the sampling bag. The attitudinal measurements were determined using the compass clinometer. A drop of dilute $\mathrm{HCl}$ was placed on the sample and effervescence was observed. The samples were sent for geochemical analysis at National Steel Raw Material Exploration Agency (NSRMEA), Kaduna.

Pulverization of the Rock Sample: The X-ray Fluorescence technique was employed. In other to determine the chemical composition of the samples, the samples were first oven-dried at a temperature of $60^{\circ} \mathrm{C}$, crushed using a disc mill to about $0.5 \mathrm{~mm}$ grain size. They were then subjected to vibrating cup miller (Herzog model) by setting the equipment at 6-8rpm. Having obtained the powdered sample of particle size 100 mesh (0.15micron), the sample is ready for the XRF machine.

Pelletization of the sample: The powdered sample is mixed with a binder, usually sodium/lithium tetraborate (Borax). The ratio of the binder to the sample to be analyzed is about 4:1 grams. This ratio of binder to sample is evenly mixed using Herzog vibrating cup miller at 8rpm. The mixture is loaded onto a cup of size $22 \mathrm{~mm}$ by $40 \mathrm{~mm}$ made of aluminum material. The pelletizing machine is operated and the pressing force is set at 240 Newtons and the movement stroke is set at 6rp. The pellet is formed ready for the $\mathrm{XRF}$ analysis.

Analyzing the sample using XRF: Pressure values are set at $16 \mathrm{~Pa}$ (Paschal), the recommended voltage level is $45 \mathrm{~V}$ and the current level is $40 \mathrm{~A}$. The equipment is allowed to run for 4-5 hours to enable the standards 
and other features responsible for analysis to stabilize (Fitton, 1997).

\section{RESULTS AND DISCUSSION}

The results from the XRF analysis is shown on Table 1. $\mathrm{CaO}$ ranges from $52.23-58.10 \mathrm{wt} \%, \mathrm{MgO}$ ranges from $0.42-0.74 \mathrm{wt} \%$, but was not detected in sample $\mathrm{G}, \mathrm{SiO}_{2}$ ranges from $7.50-10.43 \mathrm{wt} \%, \mathrm{Fe}_{2} \mathrm{O}_{3}$ ranges from $2.62-5.15 \mathrm{wt} \%, \mathrm{Al}_{2} \mathrm{O}_{3}$ from $2.30-3.40 \mathrm{wt} \%$,
$\mathrm{MnO}$, from $0.01-0.09 \mathrm{wt} \%, \mathrm{~K}_{2} \mathrm{O}$ from $0.32-$ $1.55 \mathrm{wt} \%$ and $\mathrm{Na}_{2} \mathrm{O}$ from $0.01-0.03 \mathrm{wt} \%$. The low $\mathrm{MnO}$ values indicates warm and humid climate during deposition of the carbonate sediments (Kotoky and Kataky, 1993). Table 2 shows the Silica Ratio (SR), Alumina Ratio (AR) and Lime Saturation Factor (LSF) of the results. The importance of this table is to determine the industrial use of the rock for the production Portland cement.

Table 1: Chemical Composition of Major Oxides from the study area (wt. \%)

\begin{tabular}{|c|c|c|c|c|c|c|c|c|c|c|c|}
\hline $\begin{array}{l}\text { Elemental } \\
\text { Oxides }\end{array}$ & $\begin{array}{l}\text { Sample } \\
\text { A }\end{array}$ & $\begin{array}{l}\text { Sample } \\
\text { B } \\
\end{array}$ & $\begin{array}{l}\text { Sample } \\
\text { C }\end{array}$ & $\begin{array}{l}\text { Sample } \\
\text { D }\end{array}$ & $\begin{array}{l}\text { Sample } \\
\text { E }\end{array}$ & $\begin{array}{l}\text { Sample } \\
\text { F }\end{array}$ & $\begin{array}{l}\text { Sample } \\
\text { G }\end{array}$ & & $\overline{\mathrm{i}}$ & ii & $\overline{\mathrm{iii}}$ \\
\hline $\mathrm{CaO}$ & 55.27 & 58.10 & 54.77 & 54.33 & 56.08 & 52.23 & 55.10 & 5.87 & 52.46 & 49.80 & 51.55 \\
\hline $\mathrm{SiO}_{2}$ & 9.36 & 9.20 & 10.43 & 10.00 & 7.50 & 8.06 & 10.43 & 2.93 & 3.76 & 6.75 & 4.91 \\
\hline $\mathrm{Fe}_{2} \mathrm{O}_{3}$ & 3.23 & 2.70 & 4.35 & 3.33 & 2.62 & 5.15 & 4.56 & 2.53 & 0.66 & 1.47 & 0.66 \\
\hline $\mathrm{Al}_{2} \mathrm{O}_{3}$ & 3.20 & 2.36 & 3.40 & 2.50 & 2.30 & 4.21 & 2.45 & 1.91 & 1.10 & 0.71 & 1.28 \\
\hline MnO & 0.06 & ND & 0.09 & ND & 0.01 & ND & ND & 0.08 & & & \\
\hline $\mathbf{K}_{2} \mathbf{O}$ & 0.34 & 0.50 & 1.05 & 0.41 & 0.32 & 1.55 & 0.45 & 1.23 & 0.18 & $\operatorname{Tr}$ & $\mathrm{Tr}$ \\
\hline $\mathrm{Na}_{2} \mathrm{O}$ & 0.02 & 0.01 & 0.02 & 0.01 & 0.01 & 0.03 & 0.01 & 0.02 & 0.22 & $\mathrm{Tr}$ & $\mathrm{Tr}$ \\
\hline MgO & 0.42 & 0.61 & 0.74 & 0.51 & 0.43 & 0.67 & ND & 0.32 & 1.23 & 1.48 & 0.63 \\
\hline $\mathrm{SO}_{3}$ & 0.13 & 0.18 & 0.53 & 0.30 & 0.21 & 0.40 & 0.41 & 0.40 & & & \\
\hline BaO & 0.08 & 0.14 & 0.23 & ND & 0.12 & 0.35 & 0.30 & 0.27 & & & \\
\hline $\mathrm{TiO}_{2}$ & 1.72 & 1.43 & 1.30 & 0.45 & 0.16 & 0.30 & ND & 1.56 & & & \\
\hline $\mathrm{Ta}_{2} \mathrm{O}_{5}$ & 0.04 & ND & 0.80 & 0.02 & ND & 0.10 & 0.03 & 0.78 & & & \\
\hline $\mathbf{E u}_{2} \mathbf{O}_{3}$ & ND & 0.01 & 0.05 & ND & ND & ND & ND & 0.04 & & & \\
\hline $\mathrm{V}_{2} \mathrm{O}_{5}$ & 0.01 & 0.01 & 0.03 & ND & 0.03 & 0.02 & ND & 0.02 & & & \\
\hline HgO & ND & 0.45 & 0.70 & 0.33 & ND & 0.30 & ND & 0.40 & & & \\
\hline $\mathrm{CuO}$ & ND & 0.01 & 0.02 & ND & 0.04 & ND & 0.01 & 0.03 & & & \\
\hline $\mathrm{Cr}_{2} \mathrm{O}_{3}$ & 0.02 & ND & 0.02 & 0.01 & 0.04 & 0.01 & 0.03 & 0.03 & & & \\
\hline $\mathrm{Ag}_{2} \mathrm{O}$ & ND & 0.04 & 0.02 & ND & 0.07 & ND & 0.03 & 0.05 & & & \\
\hline $\mathrm{In}_{2} \mathrm{O}_{3}$ & ND & 0.01 & 0.02 & 0.01 & 0.04 & ND & ND & 0.03 & & & \\
\hline $\mathrm{NiO}$ & 0.01 & ND & 0.01 & ND & ND & 0.01 & ND & 0.01 & & & \\
\hline LOI & 27.20 & 24.20 & 23.13 & 27.80 & 30.01 & 26.78 & 25.93 & 5.81 & 40.38 & 39.65 & 40.76 \\
\hline
\end{tabular}

$\mathrm{Fe}_{2} \mathrm{O}_{3}$ as Total Fe; $\mathrm{ND}=$ not detected; Reference Limestone Samples (i) - (iii) are from Cement Technology Course Volume (JAO-Geotect, 1987)

Table 2: Comparison of the industrial utilization of samples

\begin{tabular}{lllllllllll}
\hline Sample & A & B & C & D & E & F & G & i & ii & iii \\
\hline SR & 2.93 & 3.90 & 3.07 & 4.00 & 3.26 & 1.91 & 4.26 & 2.53 & 2.01 & $1.90-2.51$ \\
AR & 0.99 & 0.87 & 0.78 & 0.75 & 0.88 & 0.82 & 0.54 & 1.94 & 5.56 & $1.50-2.50$ \\
LSF\% & 852 & 710 & 910 & 724 & 739 & 1106 & 753 & 320 & 307 & $242-417$ \\
CaO/MgO & 131.59 & 95.25 & 74.01 & 106.53 & 130.42 & 77.96 & - & 81.88 & 171.00 &
\end{tabular}

Sample A-G $=$ Samples from study area; Reference limestone samples (i) \& (ii) are from Cement Technology Course Volume (JA O-Geotect, 1987). Standard values (iii) from Cement Course Volume (JAO-Geotect, 1987)).

The SR values for the studied samples are higher than the reference samples (i) \& (ii) but the AR of the studied samples are less than those of the reference samples (Table 2). The LSF values for the studied samples are higher than those of the reference samples. This is probably due to the high $\mathrm{Al}_{2} \mathrm{O}_{3}$ content of the reference samples. The very high values of LSF of the studied samples may also be due to the fair values of $\mathrm{Fe}_{2} \mathrm{O}_{3}$ and $\mathrm{SiO}_{2}$ in the samples. The high values of $\mathrm{Al}_{2} \mathrm{O}_{3}, \mathrm{Fe}_{2} \mathrm{O}_{3}$ and $\mathrm{SiO}_{2}$ content in the study area may be connected to the associated rocks namely, migmatites, in the area. The general standard values for SR, AR and LSF are 2.51, 2.31 and $242-417$, respectively (JAO-Geotect, 1987). In other to achieve the above values, appropriate portions of raw materials rich in shale, laterite and silica-rich materials must be added to the mix to boost the AR and SR values in other to meet the requirement for the production of Portland cement. The high $\mathrm{CaO} / \mathrm{MgO}$ ratio is an indication of the low salinity condition during the formation of carbonate rocks (Marshner, 1968) prior to metamorphism. It is also an indication of the closeness to the shoreline during the period of deposition (Bora et al., 2013). The high $\mathrm{CaO} / \mathrm{MgO}$ values $(74.01-131.59)$ is an indication that the marble in the study area are calcite dominated, hence the marble can be characterized as pure marble or high quality marble (Todd, 1966). The $\mathrm{CaO} / \mathrm{MgO}$ values are high and comparable to those of Mfamosing limestone, Jakura and Akure marble, Southwestern Nigeria (Ekwueme, 1995; Ofulume, 1993; Emofurieta and Ekuajemi, 1995). The metasedimentary 
succession of the non-carbonate sediments indicates that the sediment possess sedimentary progenitors. This is revealed by the plot of $\mathrm{Na}_{2} \mathrm{O} / \mathrm{Al}_{2} \mathrm{O}_{3}$ versus $\mathrm{K}_{2} \mathrm{O} / \mathrm{Al}_{2} \mathrm{O}_{3}$ (Figure 3) according to Garrel and Mackenzie, (1971).

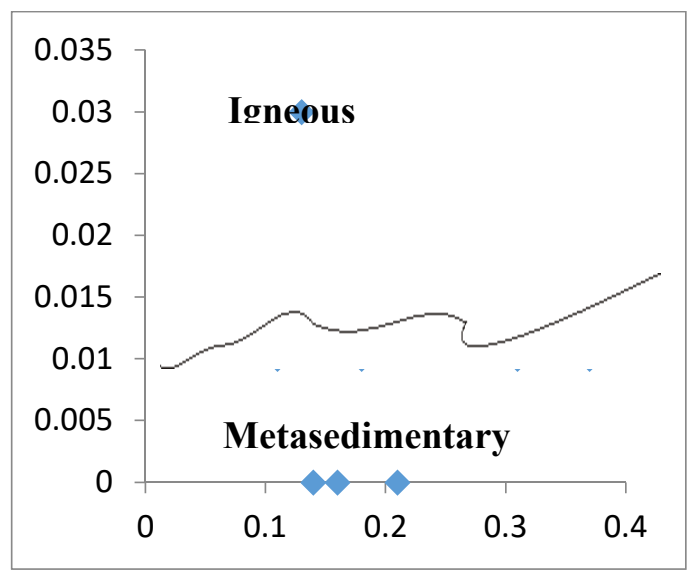

Fig 3: The metasedimentary plot of $\mathrm{Na}_{2} \mathrm{O} / \mathrm{Al}_{2} \mathrm{O}_{3}$ vs $\mathrm{K}_{2} \mathrm{O} / \mathrm{Al}_{2} \mathrm{O}_{3}$ (modified after Garrel and Mackenzie, 1971)

Figures 4 to 7 shows the relationship between $\mathrm{CaO}$ and $\mathrm{SiO}_{2}, \mathrm{Fe}_{2} \mathrm{O}_{3}, \mathrm{Al}_{2} \mathrm{O}_{3}$ and $\mathrm{MgO}$. In Figure 4, the plot shows a very weak positive relationship between $\mathrm{CaO}$ and $\mathrm{SiO}_{2}$. This is a reflection of the presence of siliceous materials probably from the incursion of remains of lower plants and animals during deposition (Baishya and Mahanta, 1994). The relationship between $\mathrm{CaO}$ and $\mathrm{Fe}_{2} \mathrm{O}_{3}, \mathrm{Al}_{2} \mathrm{O}_{3}$ and $\mathrm{MgO}$ as shown in Figure 5, 6 and 7 is a strong but negative one which reveals that as $\mathrm{CaO}$ increases, $\mathrm{Fe}^{2+}, \mathrm{Al}^{3+}$ and $\mathrm{Mg}^{2+}$ decreases (Bora, 2013). The bivariant plot between $\mathrm{CaO}$ and $\mathrm{Fe}_{2} \mathrm{O}_{3}$ indicates a slightly reducing environment (Wolf et al., 1967). It probably also depends on the availability of the materials in the basin, the chemistry of the ions and the effect of the environmental conditions that played out during deposition (Bora et al., 2013; Odokuma-Alonge and Amadin, 2018).

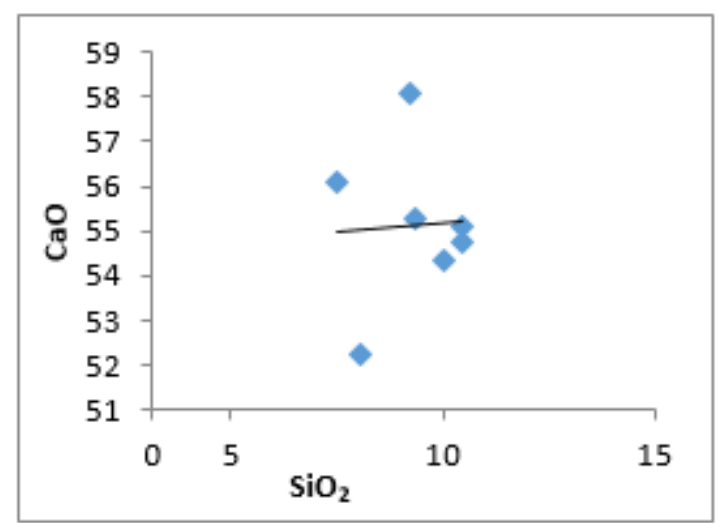

Fig 4: A plot of $\mathrm{CaO}$ vs $\mathrm{SiO}_{2}$ showing a weak

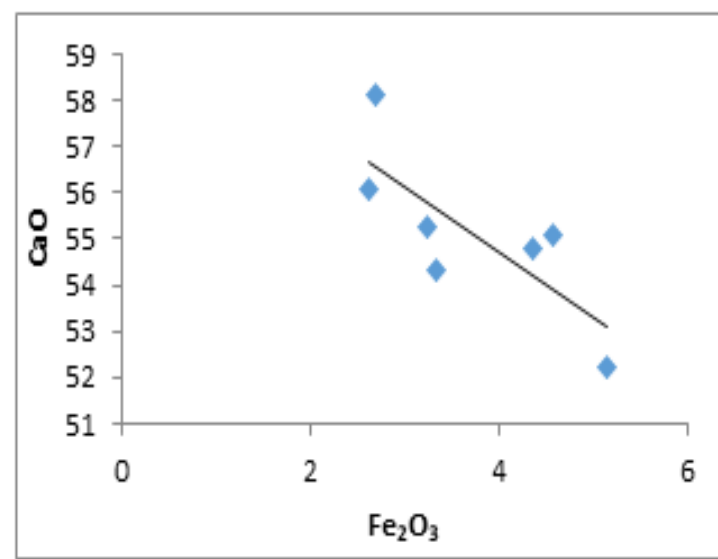

Fig 5: A plot of $\mathrm{CaO}$ vs $\mathrm{Fe}_{2} \mathrm{O}_{3}$ showing a positive relationship. Strong negative relationship

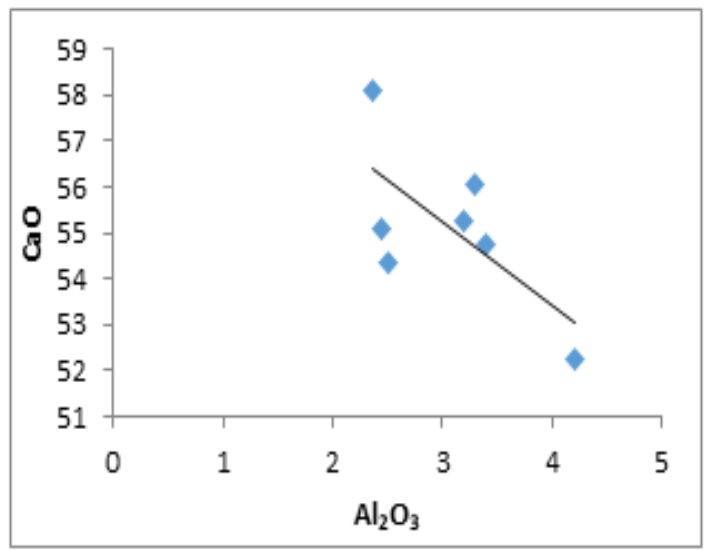

Fig 6: A plot of $\mathrm{CaO}$ vs $\mathrm{Al}_{2} \mathrm{O}_{3}$ showing a strong

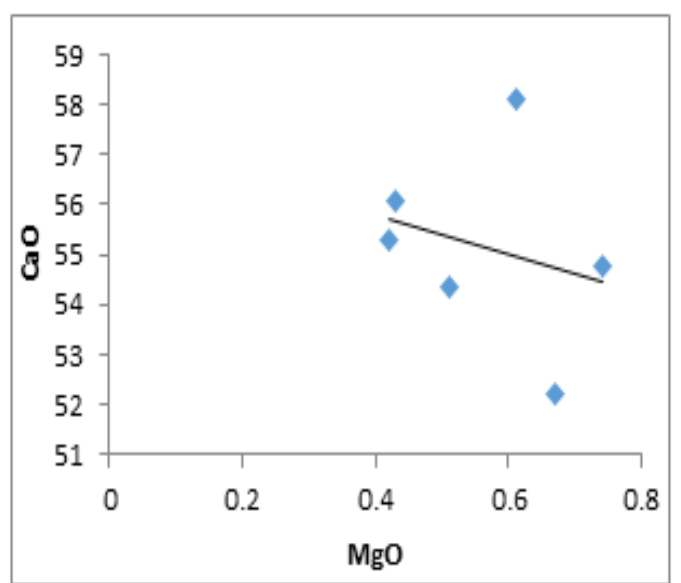

Fig 7: A plot of $\mathrm{CaO}$ vs $\mathrm{MgO}$ showing a negative relationship fairly strong negative relationship

Conclusion: The study area reveals that the marble bodies are emplaced within the schists in the western axis (Ikpeshi) and the migmatites towards the northeastern axis (Ubo River Area). Determination of the major oxides in the samples shows a high content of lime in the area. The metasedimentary succession agrees with the assertion that the non-calcareous 
sediments have sedimentary progenitors. The very high $\mathrm{CaO} / \mathrm{MgO}$ ratios and the high content of $\mathrm{CaO}$ in the rocks makes these marble to be considered as very good raw materials for the industrial sector.

\section{REFERENCES}

Ajibade, AC; Fitches, WR (1988). The Nigerian Precambrian and the Pan African Orogen. In: Precambrian Geology of Nigeria (Edited by Okezie C. N.) GSN, Kaduna pp. 45 - 53.

Baishya, DK; Mahanta, SK (1994). A geochemical study of Sylhet Limestone around Umrangchu Area, North Cachar Hills District, Assam. Bull. Ind. Geol. Assoc. 27 (1) 63-67

Bassey, EE (2011). Compositional appraisal and quality implications of a metacarbonate deposit occurring in parts of Southwestern Nigeria, RMZ - Mat. Geo-environ. 58(4). 405 - 420.

Bora, M; Das KP; Bhajabarty, B; Borah, MA (2013). Geochemical study of limestones of Shella Formation occurring in and around ShellaIshamati area, East Khasi Hill District, Meghalaya, India. Inter. J. Appl. Nat. Sci. 2 (5), 46-64

Boynton, RS (1980). Chemistry \& Technology of Lime and Limestone, John Wiley and Sons Limited, London.

Dada, SS; Tubosun, IA; Lancelot, JR (1993). Late Archean $\mathrm{U}-\mathrm{Pb}$ age for the reactivated basement of northeastern Nigeria. Pg. $405-412$.

Ekwueme, BN (1995). The Precambrian geology of Oban Massifi Southeastern Nigeria. In: Ekwueme, B. N., Nyong, E. E. and Peters, S. W. (eds), Geology Excursion guide to Oban Massif Calabar Flank \& Manfe Embayment, Southeastern Nigeria. Dec-Ford Publishers Ltd., Calabar, pp. $1-13$.

Emofurieta, WO; Aganbi, EG (2008). The geology mineralogy and geochemistry of the Ikpeshi and Okpella marble deposits in Etsako \& Akoko-Edo districts of Edo State. Nig. J. Appl. Sci. 26. 165 -180 .

Emofurieta, WO; Ekuajemi, VO (1995). Lime products and economic aspects of Igbet, Ososo \& Jakura marble deposits in SW - Nigeria, J. Min. Geol. 31, (1). 79- 89.

Fitches, WR; Ajibade, AC; Egbuniwe, IG; Holt, RW; Wright, JB (1985). Late Proterozoic Schist belts and Plutonism in Southwestern Nigeria. Geol. Soc. Of London. Pg. 319 - 337.

Fitton, V (1997). Practical X-ray Spectrometry. Pg. 54 -67 .

Garrel RM; Mackenzie, MI (1971). Evolution of Sedimentary Rocks, W.W. Worton and Co. Inc. New York.

GSN, (1974). Geological Survey of Nigeria, Auchi Sheet 266

Gillen, C (1982). Metamorphic geology: An introduction to tectonic \& metamorphic processes. George Allen \& Unwin Publishers Ltd, London, UK Pgs. 1 and 31

Grant, NK; Hickman, M; Burkhotder, FF; Powell, JL (1972). Kibaran Metamorphic Belt in Pan African domain of West Africa. Nature Physical Science Pg. $90-99$.

JAO-GEOTECT, (1987). Survey of Okpella marble deposit. Unpubl. Consultancy Report, Bendel Cement Company Limited, Bendel State, Nigeria.

Kotoky, P; Kataky, T (1993). Geochemistry of Siju Limestone, West Garo Hills, Meghalaya, Ind. J. Geochem. 8 (1 and 2). 25-36

Marshner, $\mathrm{H}$ (1968). $\mathrm{Ca} / \mathrm{Mg}$ distribution in carbonate rocks from the Lower Keuper in NW Germany (Development in carbonate sedimentology in Central Europe), Ed. Pp. 127-135

Obasi, RA (2012). Geochemistry and appraisal of the economic potential of calc-gneiss and marble from Igarra, Edo State, Southwest, Nigeria. ARPN J. Sci. Technol. 2(10). 1018 - 1021.

Obasi, RA; Anike, OL; Ogunbiyi, PI (2015). Trace and rare earth elements geochemistry of marble from Ikpeshi, its provenance and paleoredox conditions. Inter. J. Sci. Technol. 4, (1). $14-25$.

Obasi, RA and Ogungbuyi, PI (2013). Petrogenetic and distribution of trace and rare earth elements in the marble from Igarra area, Southwest, Nigeria. J. Environ. Earth Sci. 3, 13. 66- 76.

Odeyemi, IB (1988). Lithostratigraphy and structural relationship of the Upper Precambrian metasediments in Igarra Area, Southwestern Nigeria. In: The Precambrian Geology of Nigeria 
(Geological Survey of Nigerian Publication), Esho Publisher, Kaduna, Nigeria pp. $111-128$.

Odokuma-Alonge, O; Amadin, J (2018). Geochemical and statistical analysis of limestone from Ewekoro and Sagamu, southwestern Nigeria. Nig. J. Appl. Sci. 36, 160-169

Ofulume, AB (1993). An assessment of the suitability of the Jakura marble for use as a flux in steel making. Nig. J. Min. Geol. 17. $1-8$.

Onimisi, M; Obaje, NG; Daniel, A (2013). Geochemical and Petrogenetic characteristics of the marble deposit in Itobe Area Kogi State, Central Nigeria. Adv. Appl. Sci. Res. 4, $44-57$.

Rahaman, MA (1988). Recent advances in the study of the basement complex of Nigeria. In: The Precambrian Geology of Nigeria (Geological Survey of Nigeria Publication), pp. $11-41$.

Rahaman, MA; Ocan, O (1978). On relationship in the Precambrian migmatitic gneisses of Nigeria. $J$. Min. Geol. 15. 23 - 32.
Robert, SB (1979). Chemistry and Technology of Lime and Limestone. A Wiley - Interscience Publication. $2^{\text {nd }}$ Edition pg. $95-158$.

Todd, TW (1966). Petrographic Classification of Carbonate Rocks. J. Sedi. Petro. 36(2), 317 - 340.

Touret, J (1997). The significance of fluid inclusions in metamorphic rocks. In: Thermodynamics in Geology (edited by Fraser, D. G.) Pg. $243-256$.

Turner, DC (1983). Upper Proterozoic Schist Belts in the Nigerian sector of the Pan African province of West Africa Precambrian Resources 21. 55 - 79.

Woakes, M; Ajibade, CA; Rahaman, MA (1987). Some metallogenetic features of the Nigerian basement. Pg. $655-664$.

Wolf, KH; Easton, AJ; Warne, S (1967). Development in Sedimentology Techniques of Examining and Analyzing Carbonate Skeletons Minerals in Rocks, pp. 253-341. 